\title{
Wind Tunnel and Field Studies of Stagnant Flow
}

\section{Upstream of a Ridge}

\author{
By Koji Kitabayashi \\ National Research Institute for Pollution and Resources, Tokyo \\ (Manuscript received 3 December 1976, in revised form 10 February 1977)
}

\begin{abstract}
Stagnant flow which appears upstream of a ridge when the airflow is stably stratified is studied by observing wind data and also by wind tunnel experiment.

Stagnant flow in the atmosphere is shown to have a strong relation to the nocturnal inversion and disappears together with it. Since in the wind tunnel, thermal conditions are kept unchanged, the stability condition is controlled by changing flow velocity. Then, the flow features are dependent on flow velocity. But when the stagnant characteristics are described with respect to the Froude number given by

$$
F_{r}=\frac{U}{(g H \Delta \theta / \theta)^{1 / 2}}
$$

both the results in the wind tunnel and atmosphere show qualitative agreement.

A stagnant flow layer where airflow is stagnant or slightly opposite to the ambient flow is found to appear when the Froude number is less than some critical value. The critical Froude number above which the stagnant flow disappears is estimated to be about 2.3.
\end{abstract}

\section{Introduction}

It is well known that in the lee of a twodimensional hill or mountain within stably stratified airflow there occurs wavy air motion called mountain lee-waves. For lee-wave motion, many theoretical and laboratory studies exist, for example, Long (1953, 1955), Scorer (1949, 1953), Queney et al. (1959). However, their works are concerned only with lee-side air motion and no consideration has been given to airflow upstream of a mountain. Sheppard (1956) presented a problem on lee-wave studies in a short contribution. He stated that in stably stratified airflow, vertical air mass motion is regulated by the buoyancy force, and airflow cannot always cross over mountain as is assumed in the lee-wave model. If the stratification is strong enough, the air mass in the lower layer may not have sufficient kinetic energy to climb up and cross over the ridge. Sheppard gave a simple estimation for the critical wind velocity for the air mass to cross over the ridge in terms of the ridge height and temperature gradient. When the air mass in the lower layer cannot cross over the ridge, then flow stag- nation would appear upstream of the ridge.

For flow stagnation in stratified flow, Kao (1965) presented a theoretical study. He studied a non-viscous and non-diffusive stratified flow over a two-dimensional barrier and showed the formation of a stagnant flow zone. He suggested that the stagnant flow is formed when the Froude number $\left(F_{r}=U /(g H \Delta / \rho / \rho)^{1 / 2}\right)$ is less than $1 / \pi$. His model is quite interesting and outstanding, but is questionable whether it can be applied directly to the atmosphere, because in the atmosphere conditions such as velocity and density stratification are not so simple as in his model, furthermore, eddy viscosity may not be negligible in the atmosphere.

To clarify the fundamental characteristics of stagnant flow upstream of a ridge, wind data in the atmosphere have been analyzed and wind tunnel experiments have also been carried out. These results were compared and the critical Froude number was estimated.

\section{Stagnant flow observed in the atmosphere}

Up to the present, nothing has been reported 
on upstream stagnant flow observed in the atmosphere. Förchtgott (1957) showed the airflow patterns around a ridge schematically; they suggest that upstream reverse flow might occur under a particular condition.

Here, we show some results of upstream stagnant flow which were observed at Mizushima in Okayama Prefecture. The wind data were obtained as part of an atmospheric diffusion research experiment for the Air Pollution Monitoring System Project promoted by the Japan Society for Promotion of the Machine Industry.

Mizushima is in the Seto-Inland Sea area facing the sea on its south-western part; hills of about 200-300 $\mathrm{m}$ high are located on the east. The topographic conditions are shown in Fig. 1. In the field experiment, pilot balloon observations were made at two sites $\left(\mathrm{P}_{1}\right.$ and $\left.\mathrm{P}_{2}\right)$ every hour from 0700 to 1600 JST. When the wind is from the west, hills on the east form a ridge, and the analysis has been done for westerly wind conditions.

Stagnant flow upstream of the ridge was observed on April 25th and 28th when the wind was westerly (normal to the ridge) and a nocturnal inversion was still in effect. The stagnant flow was detected at both $\mathrm{P}_{1}$ and $\mathrm{P}_{2}$, but it was rather remarkable at $\mathbf{P}_{2}$. Probably, this is due to the difference of topographic conditions. Site $P_{1}$ is located upstream of a narrow valley which separates the ridge into two parts, valley wind would then have influenced the airflow at $P_{1}$. The west to east cross-sections of topography along $P_{1}$ and $P_{2}$ are shown in Figs. 2-a and 2-b. The ridge is not typical of theoretical or laboratory models, but it consists of several hills, rather close to a plateau form.

The observed hourly wind profiles from 0700 to $1000 \mathrm{JST}$ on April 25th at sites $\mathrm{P}_{1}$ and $\mathrm{P}_{2}$ are shown in Figs. 3-a and 3-b. The vertical profiles of temperature for these hours are displayed in Fig. 3-c. The wind velocity near the ground surface decreases sharply, and the profiles are convex upward. They are similar to the profiles in the wind tunnei to be discussed later. At site $\mathrm{P}_{2}$, a reverse flow layer where the wind direction is opposite to the upper layer is seen below $100 \mathrm{~m}$ at 0700 and $0800 \mathrm{JST}$. The radio sonde soundings before 1000 JST show that a strong inversion existed below $300 \mathrm{~m}$ where the temperature was almost constant with the height. The reverse flow layer dissipated before 0900 JST and the convex velocity profile disappeared by 1000 JST. The observations show that the

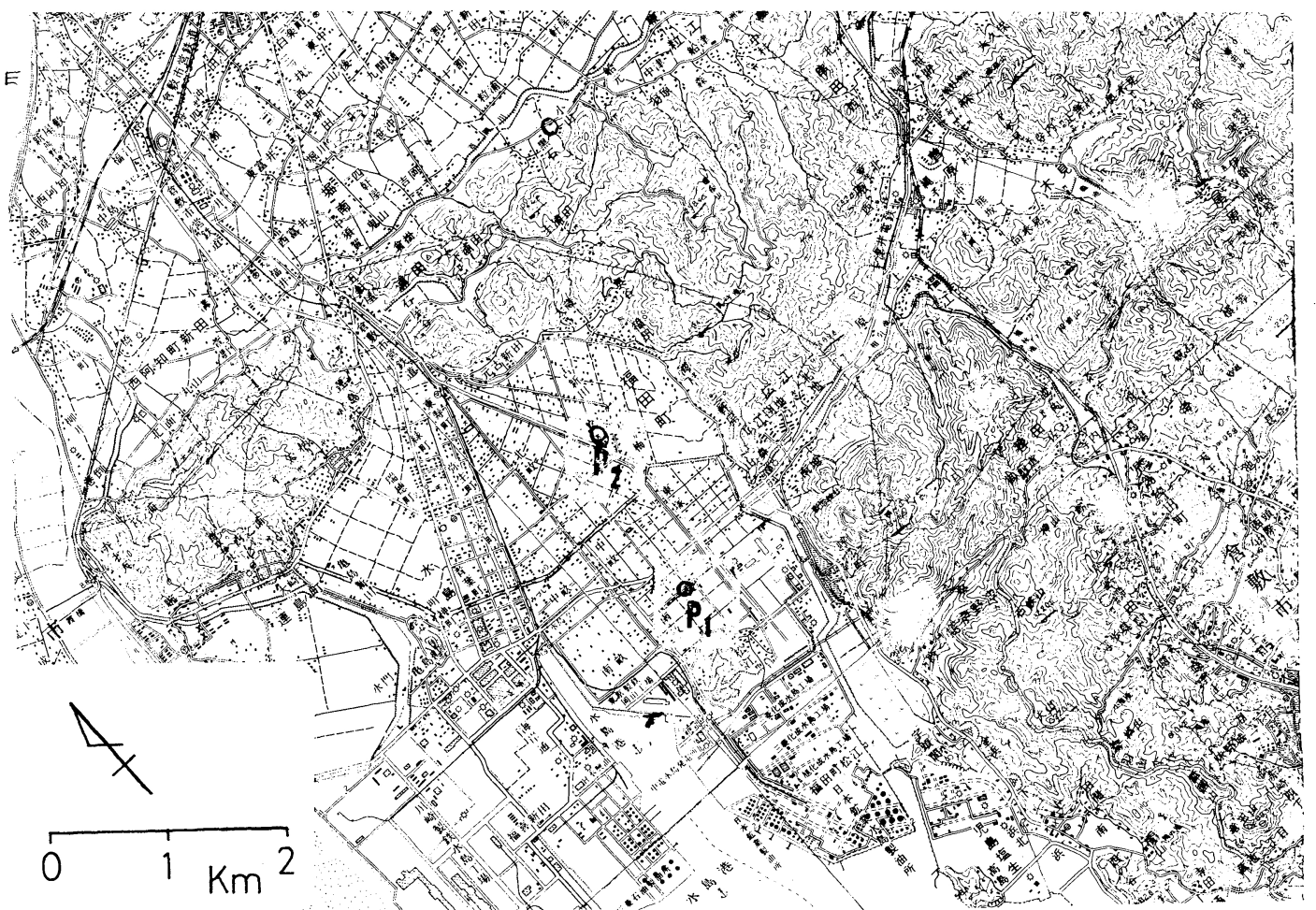

Fig. 1 Topographic condition around pilot balloon observation site in Mizushima. 


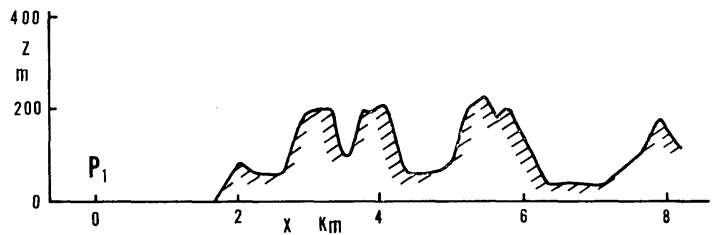

Fig. 2a West-east cross section of topography through $\mathrm{P}_{1}$ point.

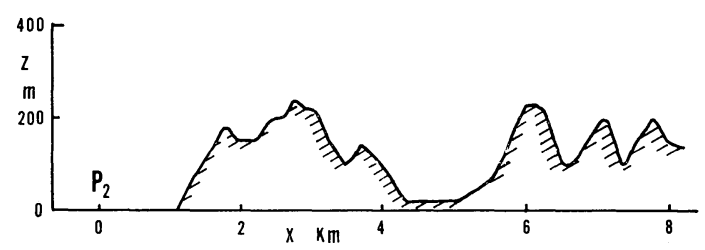

Fig. 2b West-east cross section of topography through $\mathrm{P}_{2}$ point.

temperature gradient was almost equal to the dry adiabatic state. This suggests that the reverse flow or convex velocity profile disappears together with the deterioration of the nocturnal inversion. Then, the velocity profile becomes uniform with respect to height.

On April 28th, reverse flow in the lower layer was observed more clearly than for the previous case. Figs. 4-a, 4-b, and 4-c show hourly velocity profiles at $P_{1}$ and $P_{2}$ and temperature pro- files for these hours. At both sites, a reverse flow layer about $200 \mathrm{~m}$ thick was observed before 0900 JST. Especially at $\mathrm{P}_{2}$, reverse flow is clearly detected. The temperature profiles on this morning show that a strong inversion existed below $300 \mathrm{~m}$ before $0900 \mathrm{JST}$, and this also suggests the strong correlation between inversion and reverse flow upstream of the ridge. The thickness of the reverse flow layer is almost equal to the height of the ridge. The velocity and temperature profiles at 1100 and 1200 JST are shown in Figs. 5-a and 5-b. These figures also indicate that the layer of reverse or convex velocity profiles disappear together with deterioration of the inversion. Actually, the reverse flow is relatively weak so that we may consider the layer as a stagnant flow zone.

\section{Wind tunnel experiments for stagnant flow}

\section{3-1. Experimental apparatus}

The wind tunnel experiments were done in the Atmosphere Diffusion Research Wind Tunnel at the National Research Institute for Pollution and Resources. The wind tunnel has a test section $3 \mathrm{~m}$ wide, $1.5 \mathrm{~m} \mathrm{high}$, and $13 \mathrm{~m}$ long (Fig. 6). The floor of the test section consists of double steel plates, and the floor temperature is controlled by supplying heated of cooled liquid to

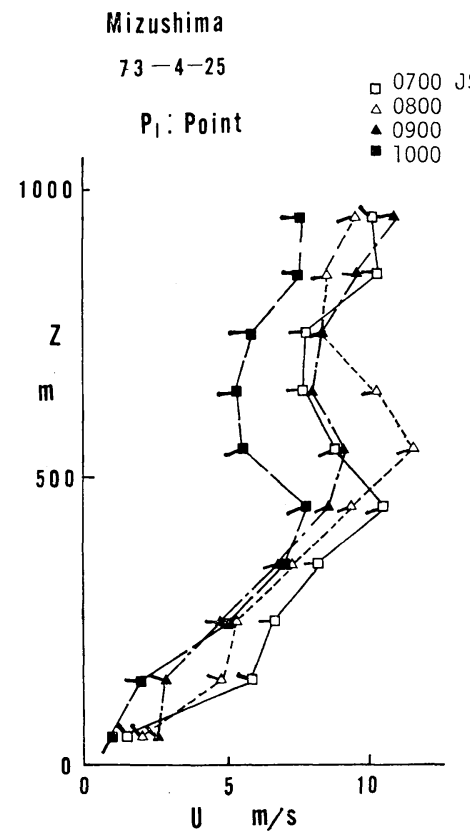

Fig. 3a Hourly wind profiles on April 25 th at $P_{1}$ point. Dashed lines show wind direction.
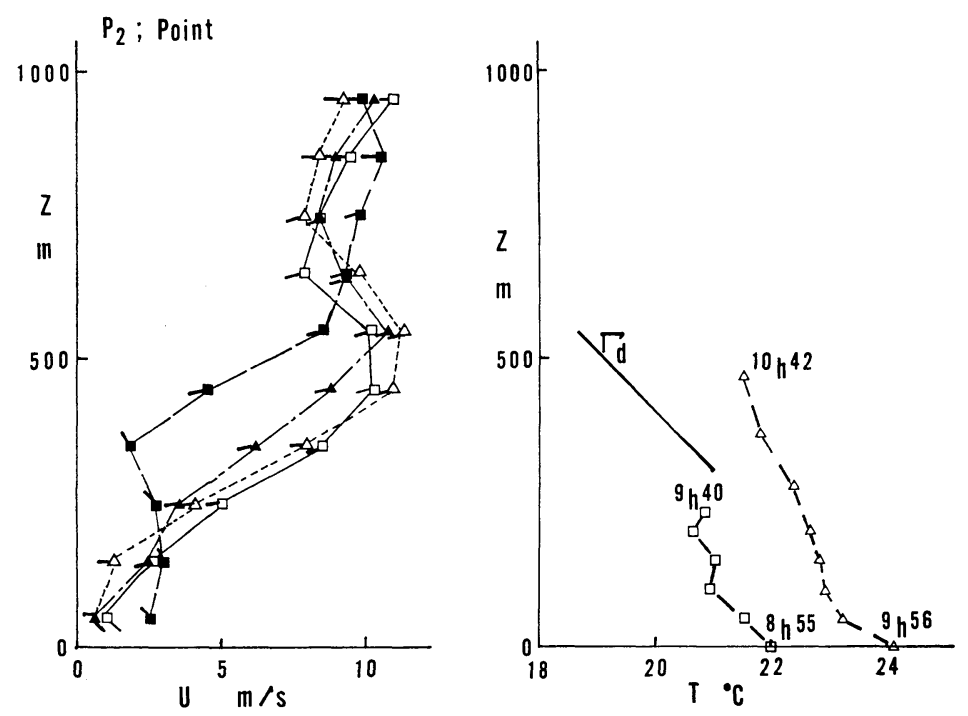

Fig. $3 b$ Wind profiles at $\mathbf{P}_{2}$ on the same day with Fig. 3-a.
Fig. 3c Vertical temperature profiles in the morning on April 25th. 


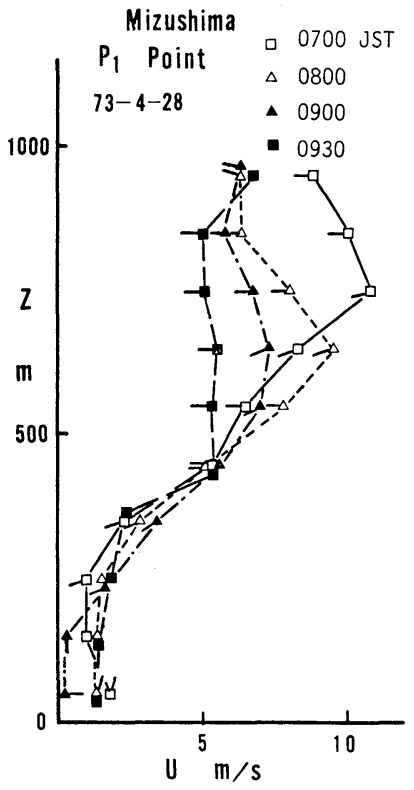

Fig. 4a Hourly wind velocity profiles and wind directions on April 2 th at $P_{1}$ point.

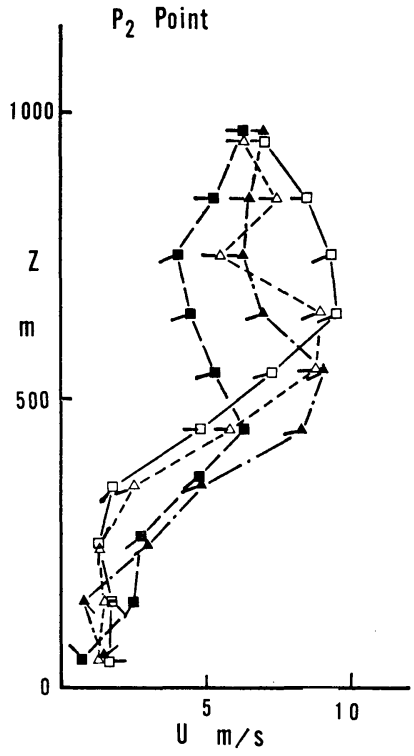

Fig. 4b Wind profiles at $P_{2}$ on the same day with Fig.

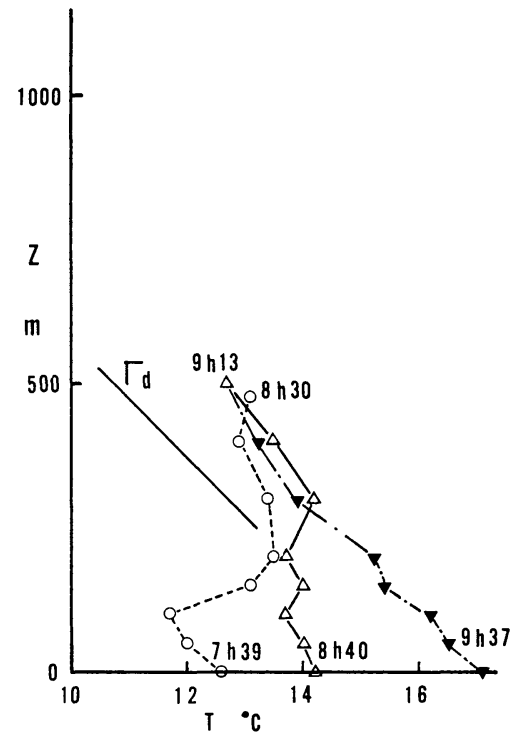

Fig. 4c Vertical temperature profiles in the morning on April 28th.

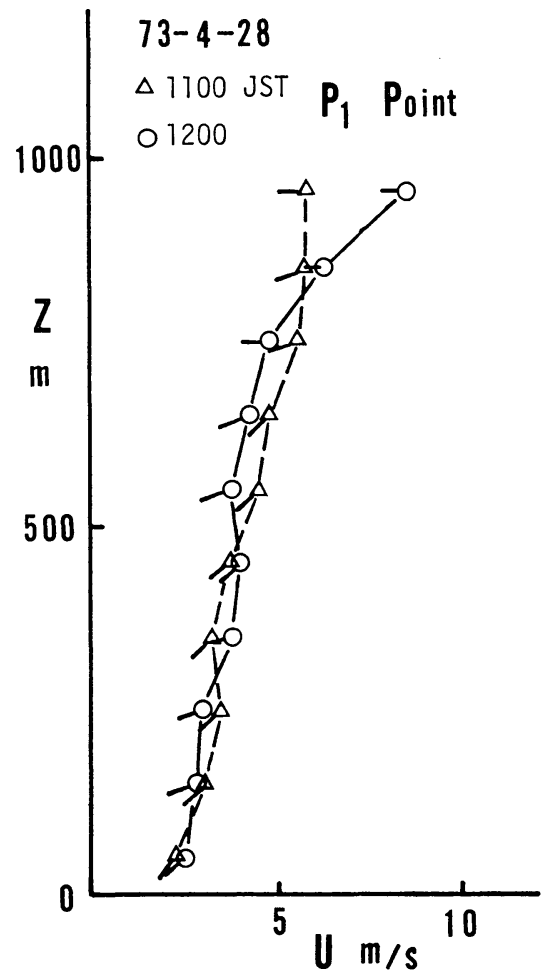

Fig. 5a Wind velocity profiles and wind directions at 1100 and 1200 JST, on April 28th.

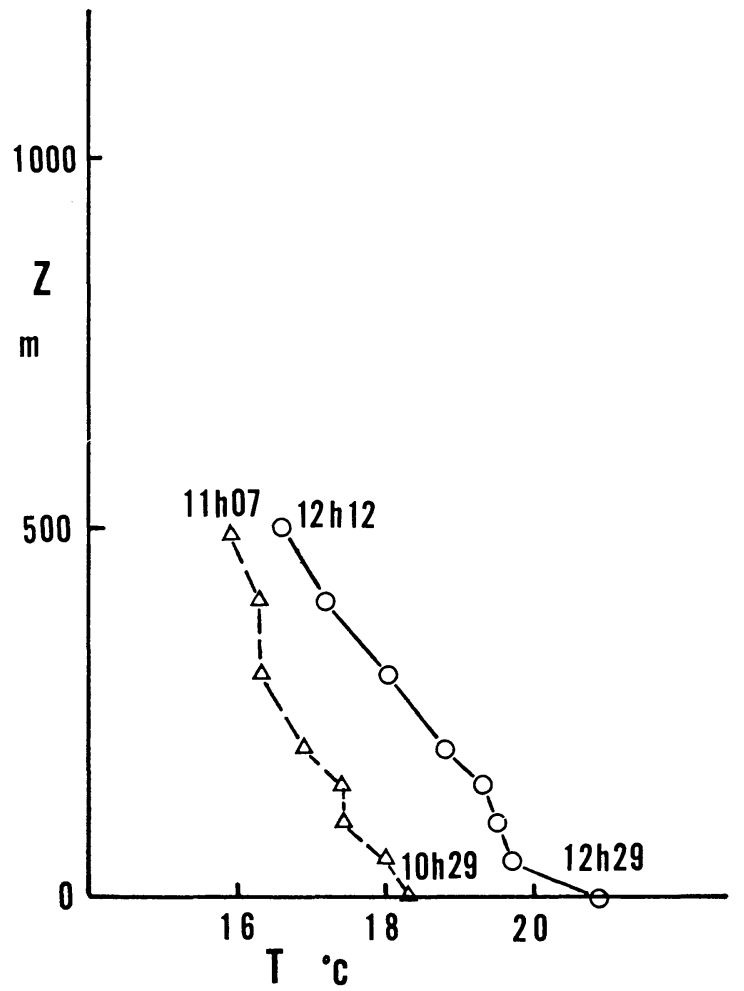

Fig. 5b Vertical temperature profiles at hours corresponding to Fig. 5a. 

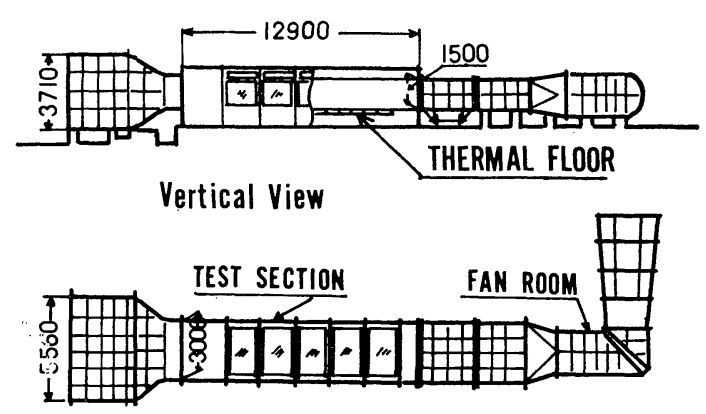

\section{Plan View}

Fig. 6 Vertical and plan view of the Atmospheric Diffusion Research Wind Tunnel. (unit: $\mathrm{mm}$ ) the space between the plates. The floor temperature is controllable between $0^{\circ} \mathrm{C}$ to $60^{\circ} \mathrm{C}$.

In the experiments, two different hill models were used. The models were made of aluminum plate. Both models were $12 \mathrm{~cm}$ high. The slope angle was different for the two models. One was 10 degrees (hereafter we call this as Model A) and the other is 15 degrees (Model B). The shapes and dimensions of the models are shown in Fig. 7.

In the wind tunnel experiment for stratified conditions, flow velocity was usually set below $1 \mathrm{~m} / \mathrm{s}$ and temperature differences of more than $20^{\circ} \mathrm{C}$ exist; therefore, hot-wire anemometer or other physical anemometry systems are not appropriate. In this study, a smoke-wire system
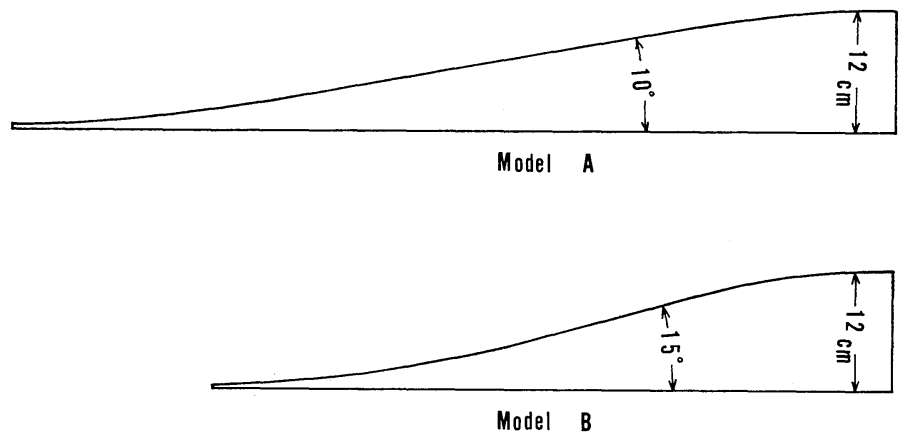

Fig. 7 Schematics of the slope models used in the wind tunnel.

which was developed for practical use at Colorado State University was utilized. The smoke-wire system is a Lagrangian trace method in which a line of smoke is produced and tracked by taking pictures sequentially. The flow velocity is calculated from the travel distance of the smoke at each time duration. The production of line smoke is done by supplying liquid parafin to a vertically stretched $50 \mu \mathrm{m}$ tungsten wire and vaporizing it by adding an instantaneous high voltage electric current to the wire. The photographs were taken by holding the shutter of a camera open and flashing a strobe sequentially at a constant time duration. The time duration of the strobe flash was 0.1 or 0.2 second and the first flash was synchronized with the smoke generation current.

\section{3-2. Stagnant flow for Model $A$}

The stably stratified flow experiment for Model A was carried out at four different flow velocities; $35,45,60$ and $80 \mathrm{~cm} / \mathrm{s}$, while the ambient flow and floor temperature were about $30^{\circ} \mathrm{C}$, and $0^{\circ} \mathrm{C}$, respectively. The hill model was located $6 \mathrm{~m}$ downstream of the entrance to the test section.
The measurements of flow velocity by smokewire system were done at four or five locations along the model hill. Three of the measuring points were on the slope, and another one or two were upstream or just at the foot of the hill. The smoke pictures were taken repeatedly four or five times at each point and velocity profiles were derived as their average.

The pictures of line smoke taken at three different measuring points at a wind velocity of $35 \mathrm{~cm} / \mathrm{s}$ are shown in the photos 1-a to 1-c. Photo 1-a shows the line smoke at $40 \mathrm{~cm}$ upstream of the model, and Photos 1-b and 1-c at the foot and at the midpoint of the slope, respectively. The time duration of the strobe flash in this case was 0.2 second. The inclined lines in the pictures correspond to the smoke at $0.2,0.4$, and 0.6 seconds after release. The taped mark on the rod of the smoke generator indicates the $10 \mathrm{~cm}$ position above the floor.

As seen in the Photos 1-a and 1-b, the line smoke is almost stationary in the bottom layer below $5 \mathrm{~cm}$. This clearly suggests that the flow is stagnant, i.e., there exists a stagnant flow layer 


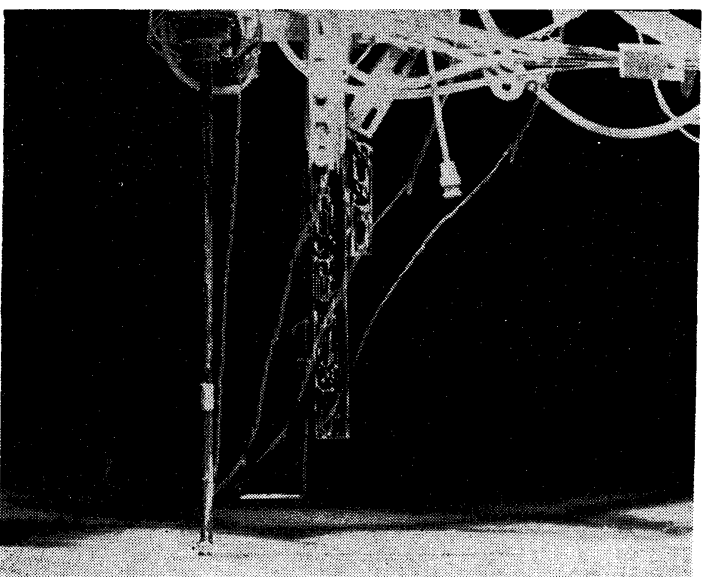

Photo 1a. Line smoke flow at $40 \mathrm{~cm}$ upstream of Model A for wind velocity $35 \mathrm{~cm} / \mathrm{s}$. Time duration of the strobe flash was 0.2 second.

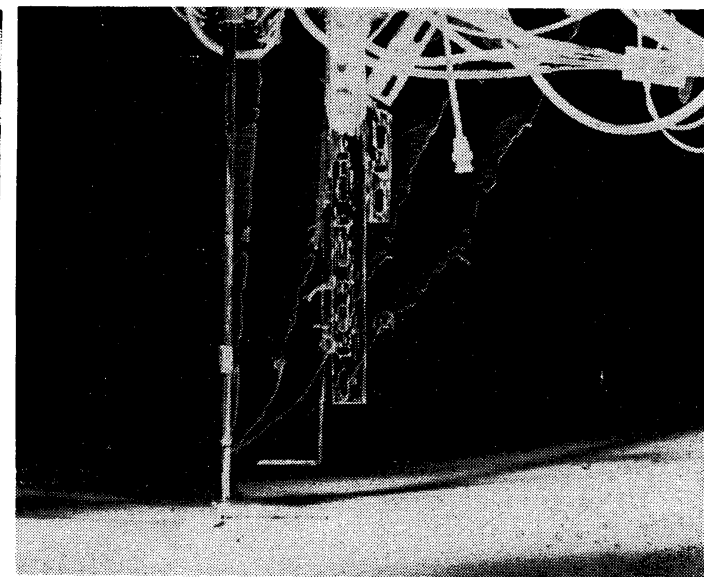

Photo 1b. Same as Photo 1a, but at the foot of the model.

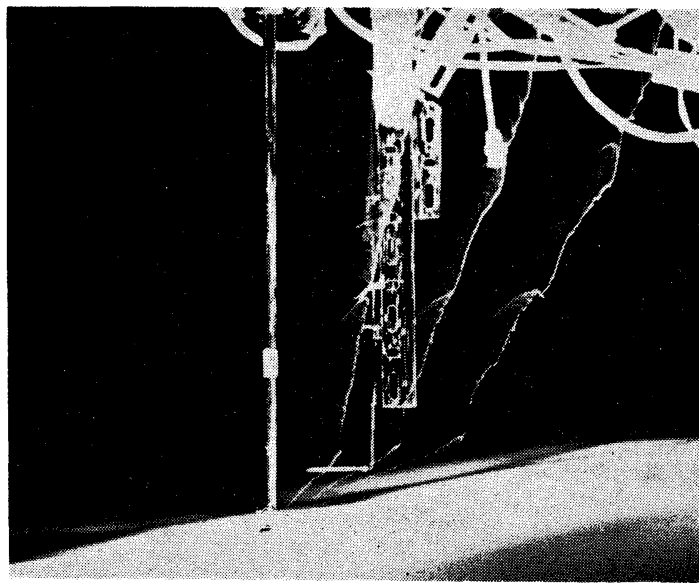

Photo 1c. Same as Photo 1a, but at the midpoint of the model slope.

below $5 \mathrm{~cm}$. The line smoke flow on the center The upstream stagnant flow layer is evidently of hill slope (Photo 1-c) is different from the other two points and does not show a velocity kink or stationary flow zone. This implies that the stagnant flow layer does not extend up to the midpoint of the slope.

Photos 2-a and 2-b show line smoke flow at a flow velocity of $60 \mathrm{~cm} / \mathrm{s}$. The thermal conditions, i.e., air and floor temperatures are almost equal to the previous case. The smoke pictures show no evidence of stationary flow and the stagnant flow is considered to be blown off at this flow condition.

The velocity and temperature profiles at several points around the model are illustrated in Figs. 8-a and 8-b for two different flow conditions. seen for a wind velocity of $45 \mathrm{~cm} / \mathrm{s}$, but not for $60 \mathrm{~cm} / \mathrm{s}$.

Even when the flow is almost laminar, velocity profiles are different from both laminar and turbulent flow. The velocity-increasing layer, which is different from the usual boundary layer, is quite thick compared to a laminar boundary layer. The airflow might have been blocked by the model hill downstream due to density stratification. The thickness of the layer decreases with an increase of flow velocity. At a flow velocity of $80 \mathrm{~cm} / \mathrm{s}$, the depth of the layer is about $10 \mathrm{~cm}$, which is almost the same as the thickness of a turbulent boundary layer under adiabatic conditions. 


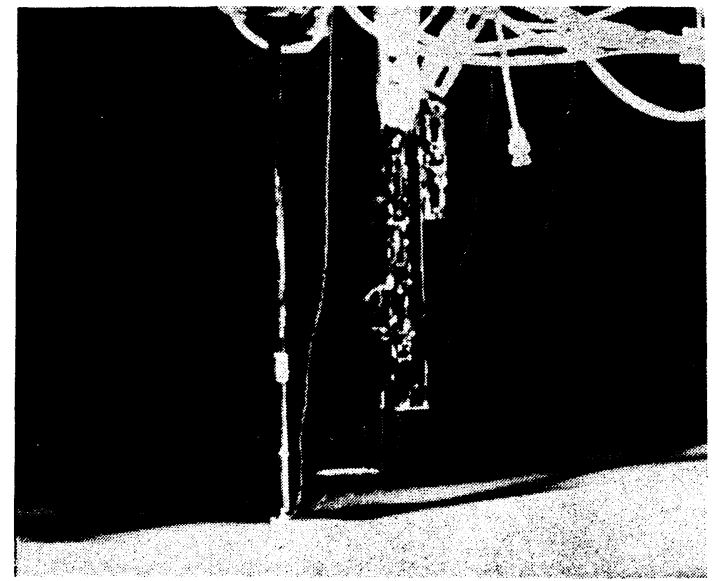

Photo 2a. Line smoke flow upstream of the model at a wind velocity of $60 \mathrm{~cm} / \mathrm{s}$. Time duration of the strobe flash was 0.1 second.

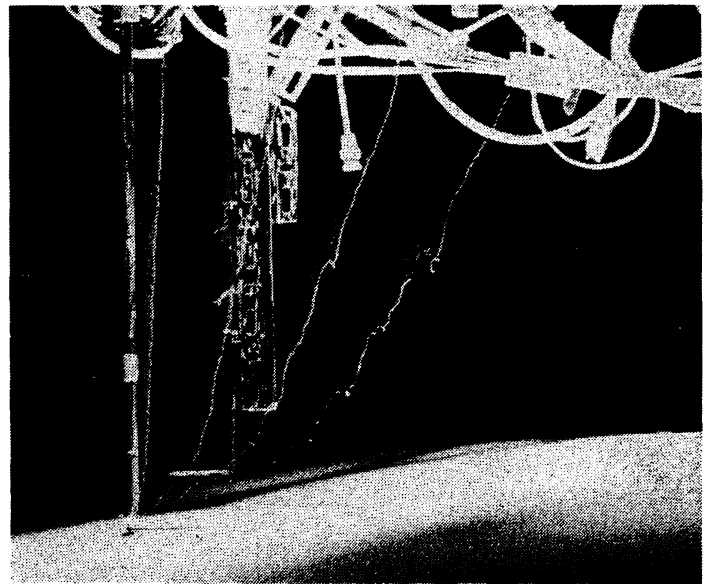

Photo 2b. Same as Photo $2 \mathrm{a}$, but at the midpoint of the model hill.

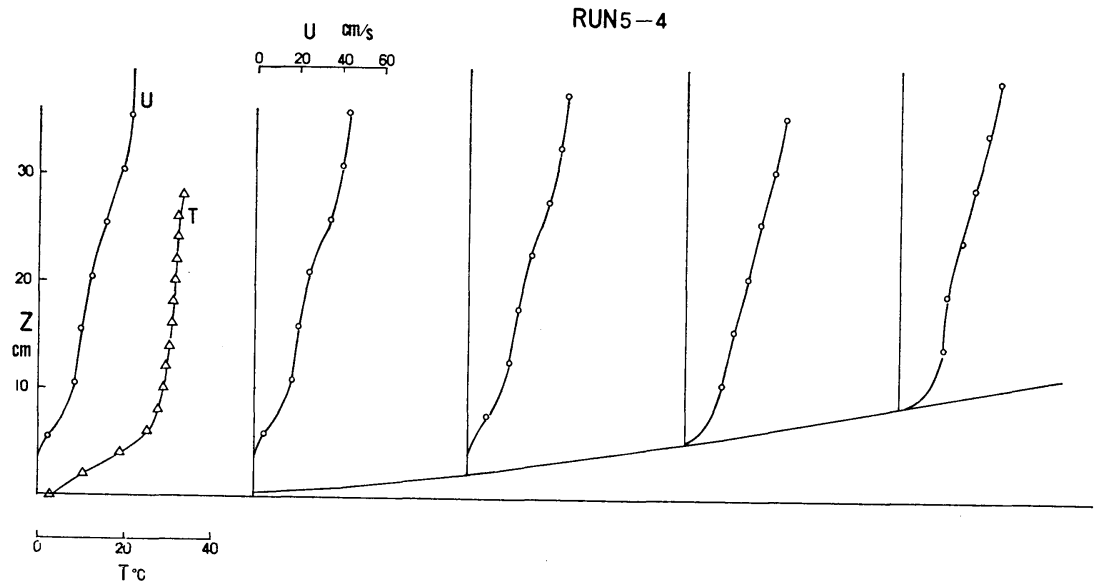

Fig. 8a Velocity profiles around the slope Model A in stably stratified flow. Ambient flow velocity is about $45 \mathrm{~cm} / \mathrm{s}$. The triangles show the temperature profile. A stagnant flow zone is seen at the foot of the model hill.

Run 5-2

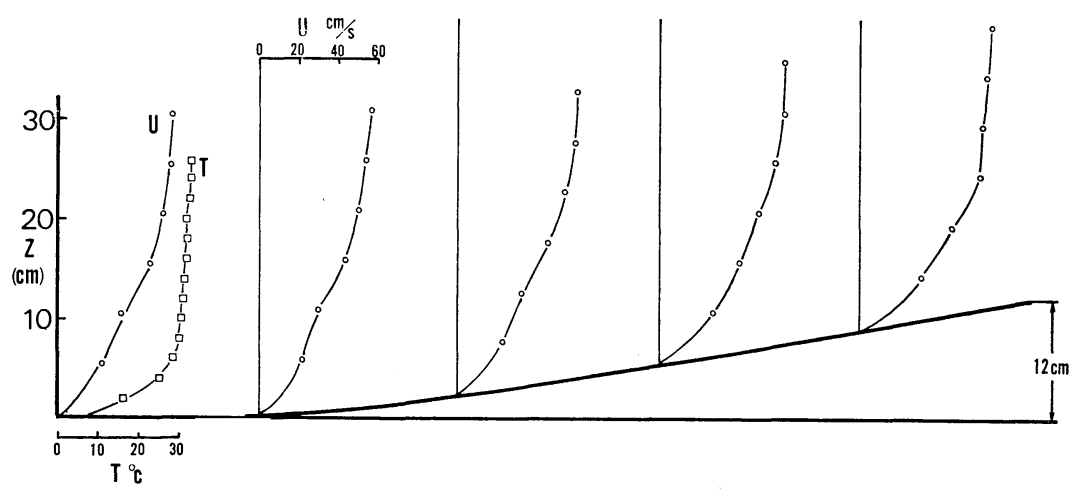

Fig. 8b Velocity profiles around the Model A at a wind velocity of $60 \mathrm{~cm} / \mathrm{s}$. Stagnant flow layer does not exist at this flow velocity. 


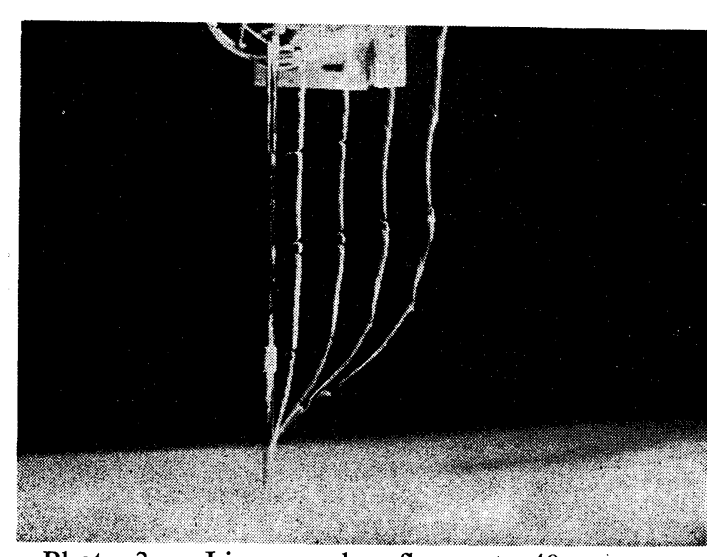

Photo 3a. Line smoke flow at $40 \mathrm{~cm}$ upstream of Model B for wind velocity of $30 \mathrm{~cm} / \mathrm{s}$. Time duration of the strobe flash was 0.1 second.

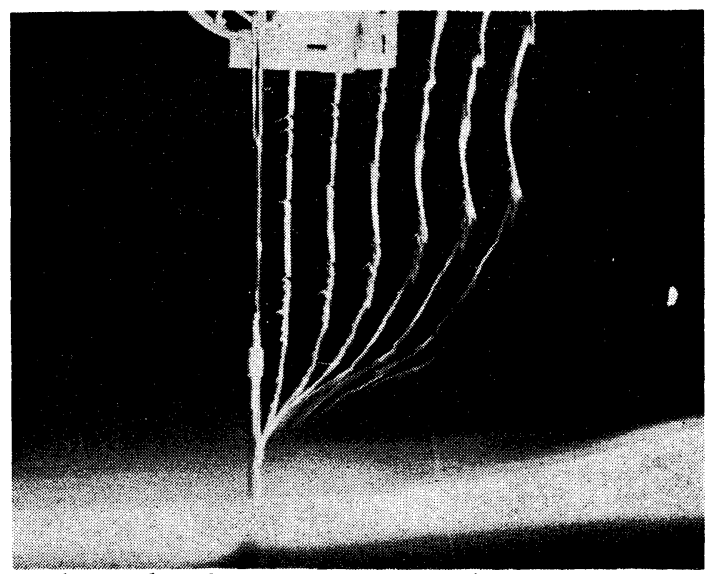

Photo 3b. Same as Photo $3 a$, but at the foot of the model hill.

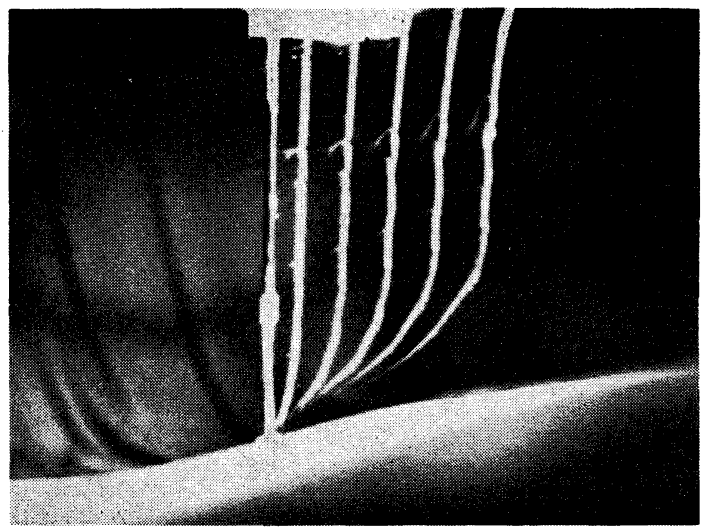

Photo 3c Same as Photo 3-a, but at the midpoint of the slope.

Run 20

Model B $\left(15^{\circ}\right) \quad T_{\infty}=25 \mathrm{~cm} / \mathrm{s}$

Sably Stratified Flow

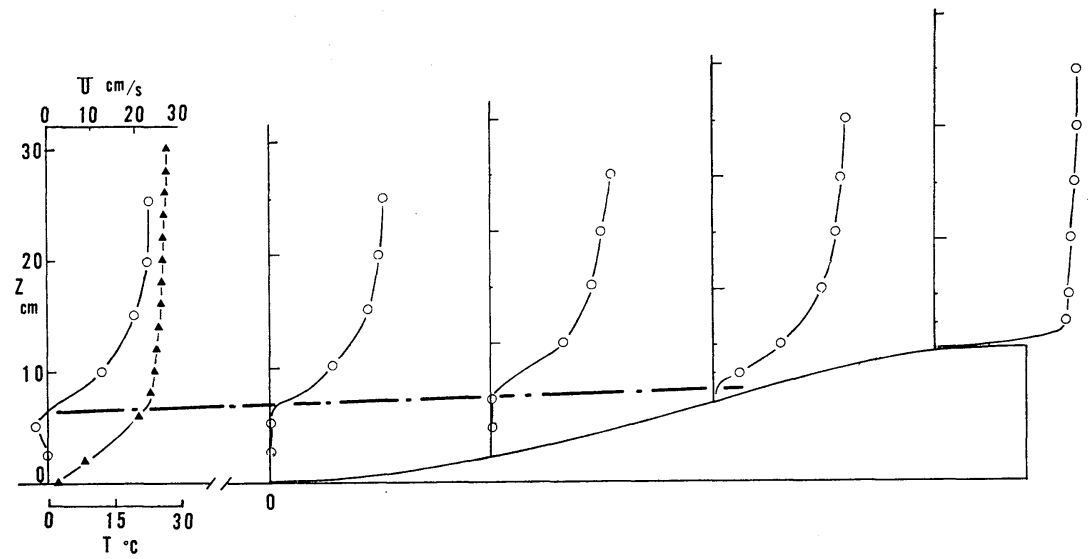

Fig. 9a Velocity profiles around the Model B in stably stratified flow. The ambient flow velocity is about $20 \mathrm{~cm} / \mathrm{s}$. A thick stagnant flow layer exists. 
Run 21

Model B $\left(15^{\circ}\right) \quad \sigma_{\infty}^{\circ}=35 \mathrm{~cm} / \mathrm{s}$

Stably Stratified Flow

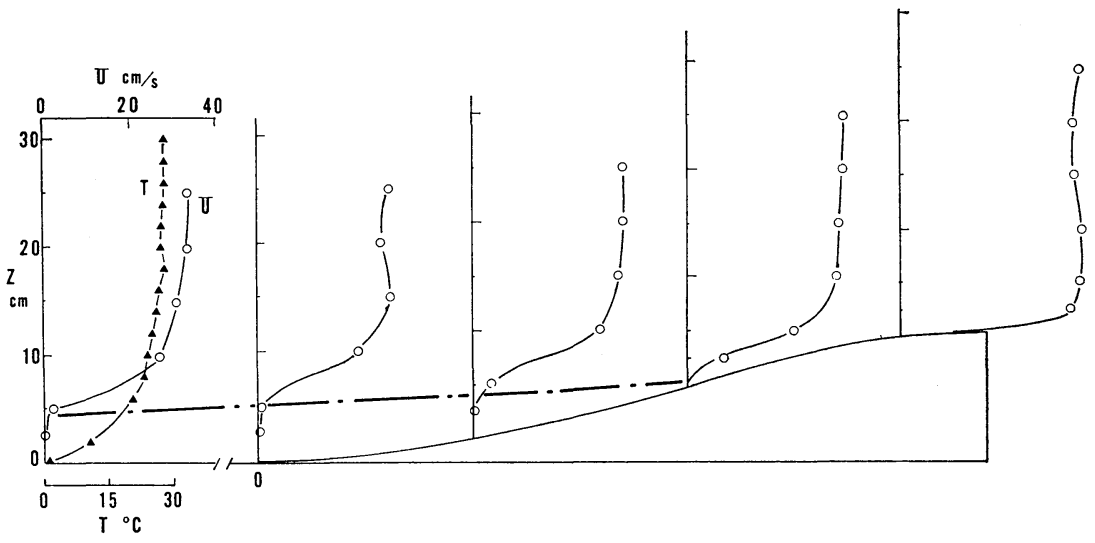

Fig. 9b Velocity profiles around Model B at a wind velocity of $30 \mathrm{~cm} / \mathrm{s}$. Temperature profile is also shown.

Run 22

Model B $\left(15^{\circ}\right) \quad \mathrm{J}_{\infty}=50 \mathrm{~cm} / \mathrm{s}$

Sably Stratified Flow

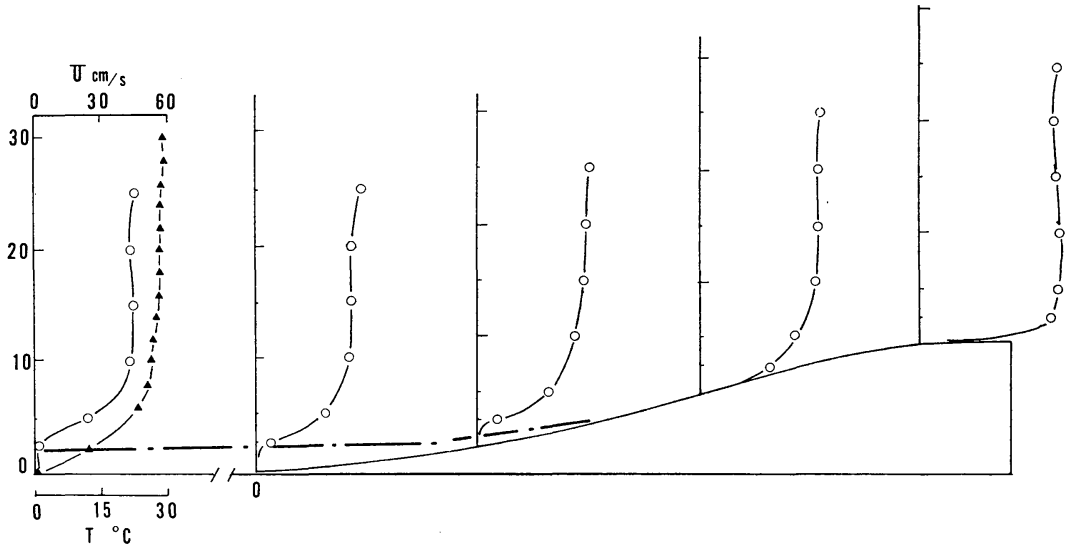

Fig. 9c Velocity profiles around Model B at a wind velocity of $40 \mathrm{~cm} / \mathrm{s}$. A thin stagnant flow zone still exists.

\section{3-3. Airflow upstream of Model B}

The wind tunnel experiments for Model B (maximum slope angle $=15$ degrees) were done for five different flow velocity conditions $(10,20$, $30,40$, and $60 \mathrm{~cm} / \mathrm{s})$. The thermal conditions are almost the same as the Model A cases.

Photos 3-a to 3-c are pictures of the line smoke taken upstream and on the slope for a flow velocity of $30 \mathrm{~cm} / \mathrm{s}$. Photo $3-\mathrm{a}$ is at the foot of the hill and Photos 3-b and 3-c on the slope. As with Model A, a stationary flow layer is seen at the bottom.

The velocity profiles for the three different flow conditions $(20,30$, and $40 \mathrm{~cm} / \mathrm{s})$ are displayed in Figs. 9-a to 9-c together with temperature profiles upstream. Generally, the flow structures are similar to those of Model A and no apparent differences are detectable. This seems to imply that the change of slope angle from 10 to 15 degrees makes no detectable differences in the flow. The stagnant flow layer is observed 
for a wind velocity range below $40 \mathrm{~cm} / \mathrm{s}$. At a flow velocity of $60 \mathrm{~cm} / \mathrm{s}$, the stagnant flow layer disappears. The critical flow velocity seems to be between 40 and $60 \mathrm{~cm} / \mathrm{s}$.

\section{Comparison of stagnant flow in two different airflows}

To make a precise comparison between the stagnant flow in wind tunnel and atmosphere, velocity profiles were normalized by reference velocity and shown in Figs. 10 and 11 for the atmosphere and wind tunnel, respectively. For the atmospheric profiles, the velocity component normal to the ridge (west component) was nondimensionalized by a reference velocity which was chosen as the average above $500 \mathrm{~m}$. The ordinate is the height above the ground normalized by the average ridge height $(250 \mathrm{~m})$. The profiles in the atmosphere show that the depth of the stagnant flow layer decreases with time and disappears at 1000 JST. The Froude number based on the ridge height, the potential temperature difference between ground and ridge level, and the reference velocity is about 1.0 at 0700 JST. It increases with time as the inversion layer attenuates and it is about 2.3 at 1000 JST. Fig. 10 is the velocity profiles at $\mathrm{P}_{2}$ on April 28th.

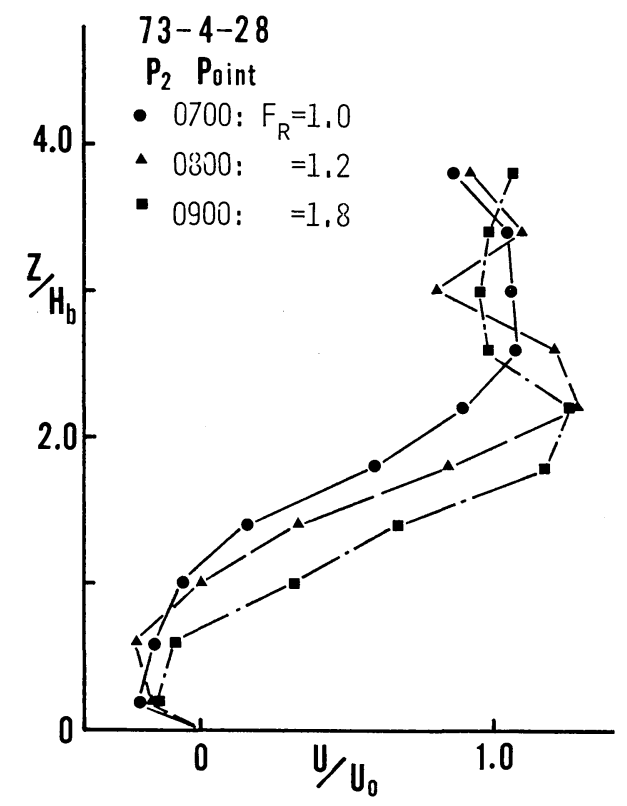

Fig. 10 Vertical profiles of normalized west component of wind on April 28th at $\mathrm{P}_{2}$ point. Abscissa is the height normalized by the average ridge height.

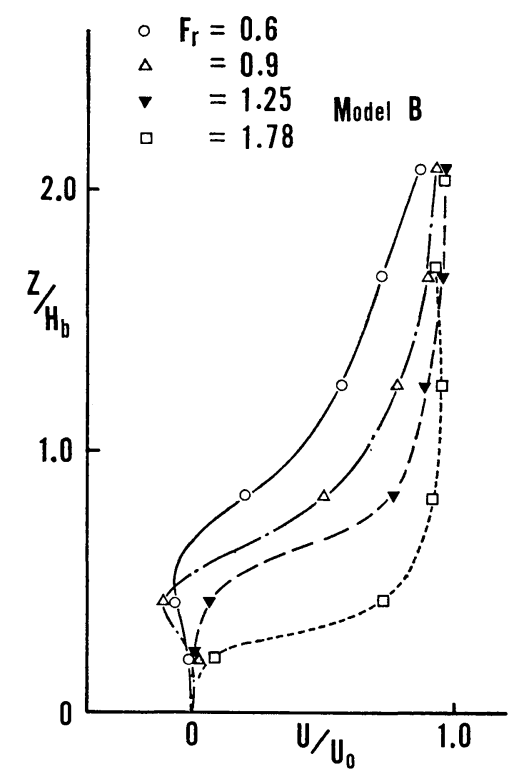

Fig. 11 Normalized vertical profiles of flow velocity upstream of Model B for different velocity conditions. Abscissa is the height normalized by the model height.

As seen in Fig. 11, the change of velocity profiles with Froude number $F_{r}$ in wind tunnel is quite similar to the atmosphere. The gradient of the velocity profile just above the stagnant layer increases with a decrease of stability.

To make a direct comparison of the relationship between stagnant flow and $F_{r}$ in both airflows, the depths of the stagnant flow layer.

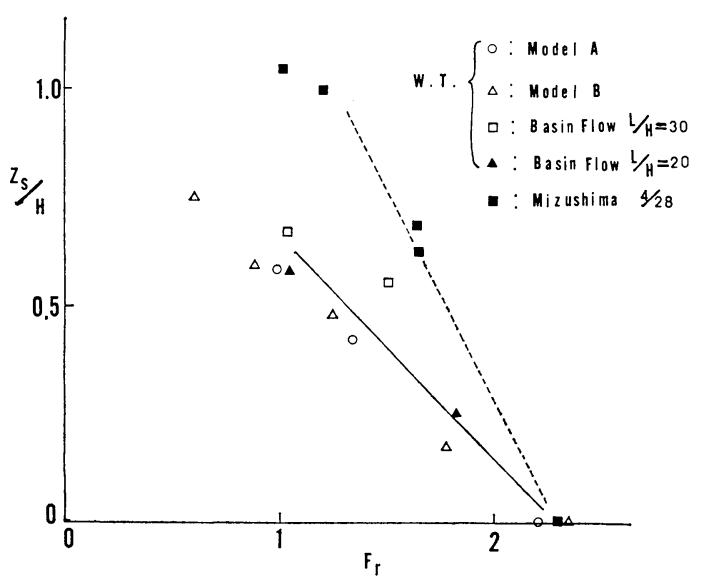

Fig. 12 Relationship between normalized stagnant zone height and Froude number $F_{r}$ for atmospheric and wind tunnel flows. In the figure, the wind tunnel results for model basins are also shown. The atmospheric data are for April 28th. 
normalized with ridge height are plotted with respect to $F_{r}$ in Fig. 12. The dependence of the depth on $F_{r}$ is similar in both flows. It decreases with $F_{r}$ and becomes zero at about $F_{r}=2.3$. This means that stagnant flow cannot exist when $F_{r}$ is greater than 2.3. This is the critical Froude number for upstream stagnant flow estimated from the wind tunnel and the atmospheric wind data.

The height of the stagnant layer in atmosphere is sometimes larger than the average ridge height and is about 1.5 times of the depth in wind tunnel in normalized scale. This can probably be attributed to the difference of ridge shape. In the model flow, the ridge is completely twodimensional and bell-shaped, whereas in the field, the ridge consists of several hills spreading over $10 \mathrm{~km}$ range. If the equivalent ridge height in the field is assumed to be about 1.5 times the actual hill height and the depth of the stagnant zone is normalized by the height, then the stagnant layer depth in the field becomes almost equal to this depth in the wind tunnel.

\section{Conclusions}

According to the analysis of atmospheric wind data and those in wind tunnel, stagnant flow is found to appear upstream of a ridge and the characteristics of the flow are clarified. The airflow data in the atmosphere have been obtained for a rather complicated ridge about $250 \mathrm{~m}$ high by theodolite tracking of pilot balloon and radio sonde sounding. The results show that a stagnant or reverse flow layer appears in the morning when a nocturnal inversion still remain and it disappears together with the decay of the inversion.

In the wind tunnel, a stagnant flow layer was produced by placing a two-dimensional model hill in thermally stratified flow produced by cooling the test section floor. The depths of the stagnant flow layer in the wind tunnel and atmosphere are shown to be governed by the Froude number $F_{r}$ and decrease linearly as $F_{r}$ increases. The critical Froude number, below which stagnant flow cannot exist, is estimated to be about 2.3 in the atmosphere and also in the wind tunnel. The critical Froude number estimated here is almost one order greater than $1 / \pi$ which was suggested by Kao from a non-diffusive and nonviscous density-stratified model. The reason of this difference is considered to be; in Kao's model, velocity and density gradient of the flow is assumed uniform with respect to height, whereas in the field and the laboratory flow, velocity and temperature profiles are not uniform but sharply change in the lower layer.

The vertical gradient of flow velocity in the upper layer of the stagnant flow zone is found to vary systematically with $F_{r}$. It increases with an increase of $F_{r}$. This flow feature is seen both in the wind tunnel and atmosphere and seems to show the effects of flow blocking of the ridge interacting with density stratification.

\section{Acknowledgments}

The author wishes to thank Dr. O. Yokoyama, chief of the Atmospheric Diffusion Research Laboratory of NRIPR for his advice and encouragement during the research. $\mathrm{He}$ also thanks to other staffmembers of the laboratory for their suggestions and discussions.

The author expresses sincere thanks to Dr. Y. Ogawa of the National Institute for Environmental Studies for useful discussions and to Mrs. P. Ogawa for correction of the manuscript.

\section{References}

Förchtgott, J., 1957: The active turbulent layer in lee of mountain ridges. Schweiz. Aerorev., Berne., $32,324$.

Kao, T. W., 1965: The phenomenon of blocking in stratified flow. J. Geoph. Res., y0-4, 815-822.

Long, R. R., 1953: Some aspect of the flow of stratified fluids, I-A theoretical investigation. Tellus, 5, 42-58.

, 1955: Some aspects of the flow of stratified fluids, III-Continuous density gradients. Tellus, \%, 341-357.

Queney, P. et al., 1959: The airflow over mountains. The world WMO. Tech. Note, 34.

Scorer, R. S., 1949: Theory of waves in the lee of mountains. Quart. J. Roy. Meteor. Soc., 75, 41-56.

, 1953: Theory of airflow over mountain, III-The flow over a ridge. Quart. J. Roy. Meteor. Soc., 79, 70-83.

Sheppard, P. A., 1956: Airflow over mountains. Quart. J. Roy. Meteor. Soc., 82, 226. 


\title{
山岳風上側よどみ流の風洞による研究
}

\author{
北 林 興 ニ \\ 公害資源研究所
}

風洞中に安定成層気流を発生させ, 二次元山岳モデルの上流側に発生するよどみ流の特性を調べ，大気中で観測さ れたものとの比較を行った。風洞実験では測定部床面を $0^{\circ} \mathrm{C}$ に冷却し, 約 $30^{\circ} \mathrm{C}$ の気流を通して温度成層流を作り, 高さ $12 \mathrm{~cm}$ の二次元山岳モデルを用いてよどみ流の特徵を調べた。この温度条件では, 気流速度が $40 \sim 50 \mathrm{~cm} / \mathrm{s}$ 以 下でよどみ流の出現が見られ，よどみ流域の厚さは風速にほぼ逆比例して減少することが示された。

大気中に打けるよどみ流は, 岡山県水島地域でのパイロットバルーン観測で, 1973年 4 月 25 日と 4 月 28 日の早朝に 見られた。この両日共, 上層で西寄りの風が吹いており, 観測点の風下側には $250 \mathrm{~m}$ 程度の丘陵が位置している。早 朝には, 地上 $300 \mathrm{~m}$ 程度まで強い接地逆転層が存在していたが, この時, 地表面近く（地上から約 $300 \mathrm{~m}$ 程度まで） に風向が上層と反対か，あるいは無風状態に近い“よどみ域”が観察された。

よどみ流の支配的なパラメータは温度あるいは密度差を取り入れたフルード数

$$
F_{r}=U /(g H \Delta \theta / \theta)^{1 / 2}
$$

であると考号れるので, 大気中と風洞中でのよどみ流域の厚さや風速分布を無次元化し $F_{r}$ 数について調べたとこ ろ, 両者の $F_{r}$ 数に対する依存性は良く一致し, その相似性が確められた。よどみ流の発生する $F_{r}$ 数の限界值は両 気流中でよく一致し，ほぼ 2.3 程度であった。 